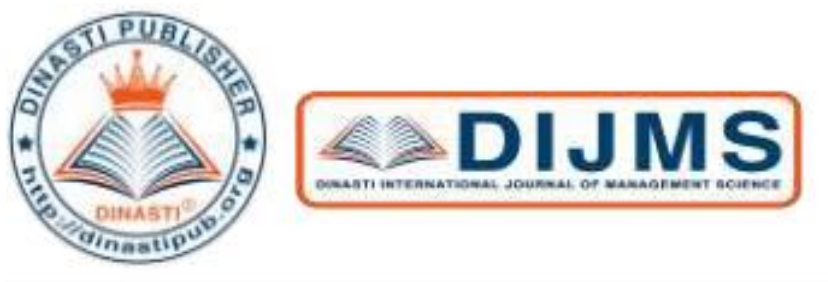

+6281387654578 ()

081387654578 ()

https://dinastipub.org/DIJMS (2)

editor@dinastipub.org (.)

\title{
THE INFLUENCE OF ORGANIZATIONAL CULTURE AND TRAINING ON ORGANIZATIONAL COMMITMENT AND ALSO ITS IMPLICATIONS ON THE PERFORMANCE OF HEALTH WORKERS IN PUSKESMAS JOHAR BARU DISTRICT
}

\author{
Handy Suryadi ${ }^{1}$, Muhammad Havidz Aima ${ }^{2}$ \\ 1) Master of Management, Mercu Buana University, Jakarta, Indonesia \\ ${ }^{2)}$ Lecturer of Postgraduate, Mercu Buana University, Jakarta, Indonesia
}

\begin{tabular}{|c|c|}
\hline $\begin{array}{l}\text { ARTICLE INFORMATION } \\
\text { Received: 27/11/2019 } \\
\text { Revised: 29/11/2019 } \\
\text { ssued: 03/12/2019 } \\
\text { Corresponding author: first author } \\
\text {-mail: } \\
\text { dr.handy.suryadi@gmail.com } \\
\text { havidz.aima@mercubuana.ac.id }\end{array}$ & $\begin{array}{l}\text { Abstract: :- The purpose of this research is to find out } \\
\text { and explain the influence of organizational culture and } \\
\text { training on organizational commitment and its } \\
\text { implications for the performance of Puskesmas Johar } \\
\text { Baru District employees. The research method uses a } \\
\text { quantitative approach, which became the population in } \\
\text { this research were } 170 \text { Health Center Staff Johar Baru } \\
\text { District. The sample selection is done by simple } \\
\text { random sampling technique (Slovin 5\% error } \\
\text { tolerance) so that as many as } 120 \text { respondents are } \\
\text { determined. Data collection techniques using } \\
\text { interviews and questionnaire instruments. The } \\
\text { questionnaire survey instrument was randomly } \\
\text { delivered to Johar Baru District's Puskesmas staff. } \\
\text { Data were analyzed using structural equation modeling } \\
\text { (SEM) with the Smart PLS software program version } \\
\text { 3.2.8. This study revealed that organizational culture, } \\
\text { training and organizational commitment had a } \\
\text { significant positive effect on employee performance, } \\
\text { both partially and simultaneously. In addition, } \\
\text { organizational commitment mediates organizational } \\
\text { culture and training on performance. } \\
\text { Keywords: Organizational Culture, Training, } \\
\text { Organizational Commitment and Employee } \\
\text { Performance. }\end{array}$ \\
\hline
\end{tabular}




\section{INTRODUCTION}

Puskesmas as the implementing unit of health development in the sub-district area is the spearhead in health services to supporting success of achieving the vision of the Ministry of Health of the Republic of Indonesia, namely as healthy Indonesia in 2025, one of which is the Johar Baru's Puskesmas. The success of Johar Baru's Puskesmas is hugely influenced by the arrangement and management of health workforce to carry out the primary activities of the puskesmas. This is because humans have potential resources to be developed continuously in each of their work activities.

Johar Baru's Puskesmas has 2 (two) service units, namely the Individual Health Efforts (UKP) service unit and the Community Health Efforts (UKM) service unit. UKP is an activity and / or series of health service activities aimed at improving, preventing, healing diseases, reducing suffering due to illness and restoring individual health, while UKM is any activity to maintain and improve health and prevent and overcome the emergence of health problems targeting family targets, groups and society. Performance achievements that refers to the Minimum Service Standards (SPM) in the UKP and UKM service units are only carried out by health workers both PNS and Non PNS status.

Based on the 2018 annual report, the number and trend of employees who have achieved performance under the "good" category has increased by 3 (three) employees in each service unit, a trend increasing by $6.18 \%$ compared to the previous two years. Achievement performance of Johar Baru's Puskesmas Sub-District employees in 2016 only reached 90.9\%, then in 2017 the performance of Johar Baru's Puskesmas Sub-District employees was $91.53 \%$ and in 2018 it was $85.03 \%$. Achievement performance of health staff at the Johar Baru's Puskesmas in the last 3 (three) years did not reach the set performance target of $100 \%$ employee performance in the "good" category.

Based on the pre-survey results it can be seen that the factors who influencing the performance of the health staff at the Johar Baru's Puskesmas are organizational culture (67\%), training (67\%) and organizational commitment (60\%).

From the background of above problems, the authors would like to conduct research with the theme "The Influence of Organizational Culture and Training on Organizational Commitment and Its Implications on the Performance of Health Staff in Puskesmas Johar Baru District".

\section{LITERATURE REVIEW Organizational Culture}

According to Irham Fahmi (2016:185) said that organizational culture is a habit that lasted a long time and used also applied in daily of work activities as one of the drivers to improve the work quality of employees and company managers. According to Robbins and Judge (2013:512) the definition of organizational culture is a system of shared meanings held by members that distinguishes organizations from other organizations. Then, Wibowo (2017:74) said that the components of organizational culture are values, norms and management styles. From this definition it can be concluded that organizational culture is a belief, attitude and value that a person has to shape people to behave and do things in accordance with organizational goals. 


\section{Training}

According to the Law of the Republic of Indonesia Number 13/2003 concerning about manpower, Manpower Training is an overall activity to provide, obtain, improve, and develop work competency, productivity, discipline, attitude and work ethic at a certain skill and expertise level according to levels and qualifications of work. According to Sumarsono (2009) in Sinambella (2018:169) said that basically training is an activity to improve the ability of employees by allocating the budget as an investment. According to Noe (2013) in Kasmir (2016: 126) states that training is a facility provided by the company to learn work related to employee knowledge, skills and behavior. This means to increase the knowledge, skills and behavior of employees can be done through training which of course has been planned by the company beforehand.

\section{Organizational Commitment}

Experts' views on the definition of commitment can be vary greatly. There are those experts who claim only commitment, but there are others who declare it as organizational commitment. Basically, commitment is individual, is / or the attitude or behavior of each individual. While the commitment of each individual to the organization where he works can be said as organizational commitment. According to Colquitt et al (2015) in Ricardianto (2018:176) said that organizational commitment is desire of a person to continue working in his organization and remain a part of an organization. Wibowo (2017:431) concluded that organizational commitment is the feelings, attitudes and behavior of individuals identifying themselves as part of the organization, involved in the process of organizational activities and loyal to the organization in achieving organizational goals.

\section{Employee Performance}

The term of performance comes from the word job performance or actual performance, namely the results of work or actual work performance achieved by someone. According to Mangkunegara (2015: 67) said employee performance is the work of quality and quantity achieved by an employee in carrying out their duties in accordance with the responsibilities given to him. According to Armstrong and Baron (1998: 15) in Wibowo (2017: 7) said performance is the result of work that has a strong relationship with strategic objectives, customer satisfaction and contribute to the economy.

\section{Conceptual Framework}

Several previous research explained that organizational culture had influenced to organizational commitment (Patra and Aima, 2018)and which in turn organizational commitment influences performance (Sakti, 2015). In addition, Organizational culture also has a direct and significant effect on performance (Wahyuni, 2015). Training has a significant effect on organizational commitment (Nugraha et.al., 2017) and also has a direct effect on performance (Riyanto, et.al.2017)

Assuming there is a link between organizational culture variables and training altogether on organizational commitment. Based on the results of research that has been stated above said that each variable has a positive effect in influencing organizational 
commitment. Then the assumption of a relationship between organizational culture variables, training and organizational commitment together influence the performance of employees. Besides that, organizational commitment who was influenced by organizational culture and training that will affect performance and so that organizational commitment can be mediated to organizational culture and training on employee performance.

Based on the results of previous Research, the theoretical framework in this research can be seen in Figure 1 below.

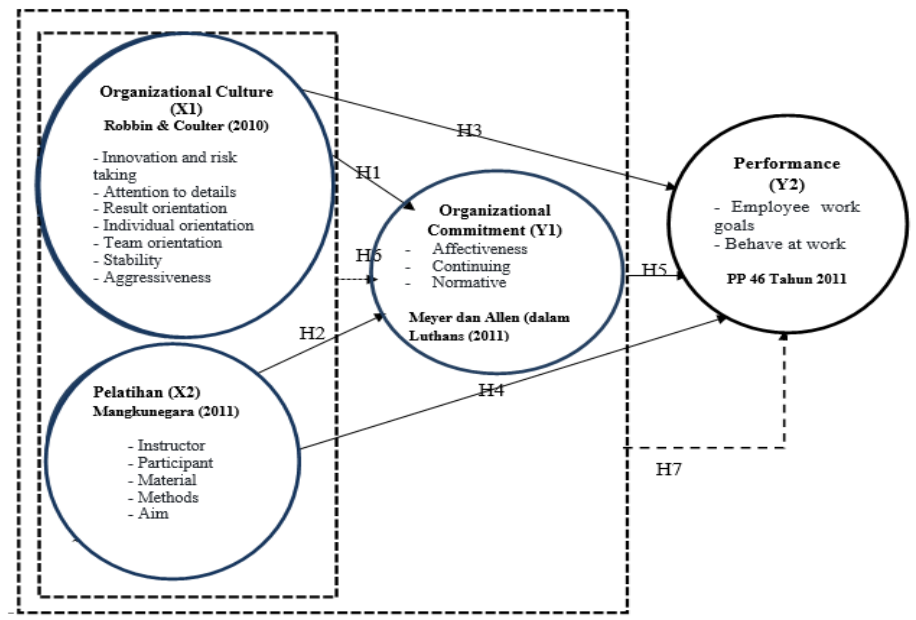

Fig. 1. Theoretical Framework

Source: Theoretical Review

\section{RESEARCH METHODS}

This type of research is quantitative research using primary data in the form of surveys. The researcher created this research to be able to understand, explain and analyze the correlation between the independent variables with the dependent variable, which in this research will be analyzed using relevant statistical data to test the hypothesis. The independent variable in this research consisted of organizational culture (X1), training (X2), while the dependent variable was organizational commitment (Y1) and employee performance (Y2).

According to Sugiyono (2013) Population is a generalization area consisting of objects or subjects that have certain qualities and characteristics determined by researchers to be studied and then drawn conclusions. The population in this research amounted to 170 people who are health employees and located in Johar Baru District's Puskesmas, Jl. Mardani Raya Number 36, Central Jakarta and all Technical Implementation Units that are spread in 5 (five) Puskesmas of Johar Baru Village. Arikunto (2013: 174) argues that the sample is part or representative of the population under study. This research uses the Slovin formula because in drawn the sampling with error level of 5\%, so we get a sample of 120 people.

This research uses data analysis techniques using SmartPLS software version 3.2.8 which is run on computer media. PLS (Partial Least Square) is a variance-based structural equation analysis (SEM) that can simultaneously test. The measurement models alongside with structural model testing. The measurement model is used to test the validity and 
reliability, while the structural model is used to test causality (hypothesis testing with predictive models).

\section{FINDINGS AND DISCUSSION}

Testing in this research uses the outer model test and the inner model test.

\section{Outer Model Test}

Evaluation of convergent validity from checking individual item reliability can be seen from the standardizef loading factor value. Standardizef loading factor illustrates the magnitude of the correlation between each measurement item (indicator) with its construct. The loading factor value used in this study is $>0.7$ so if the loading factor value is $<0.7$, the indicators in this study will be excluded from the model.

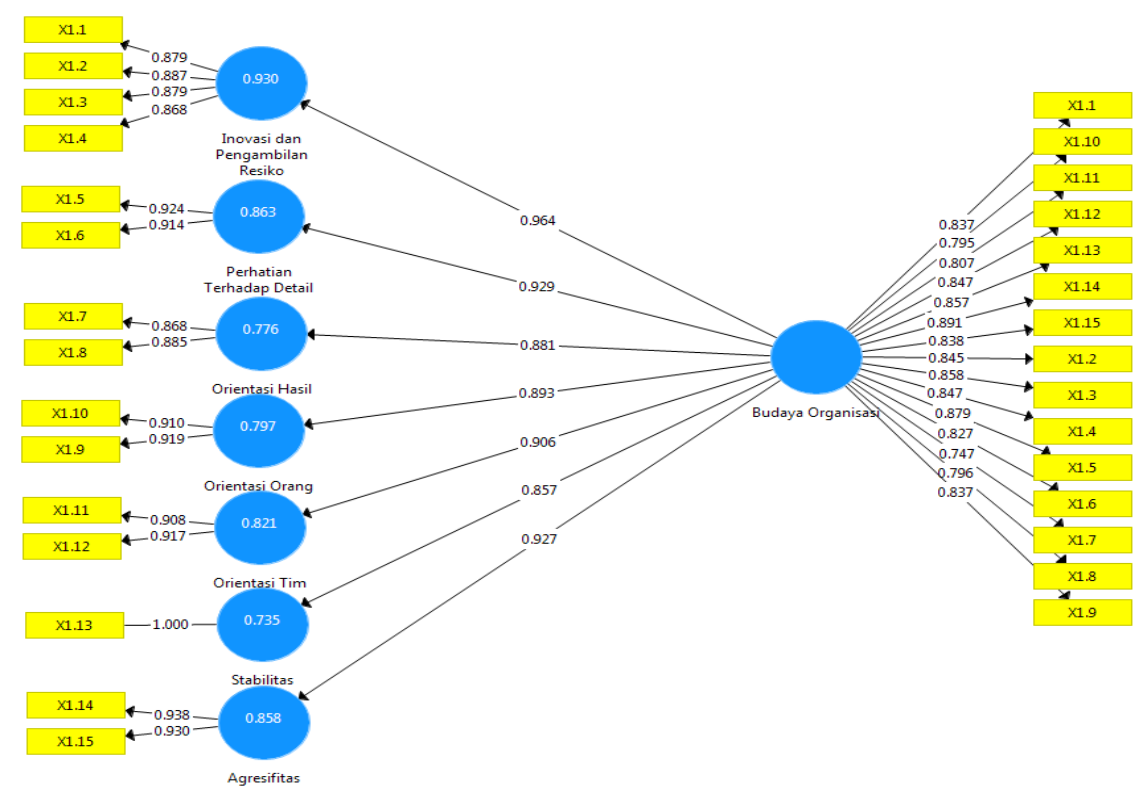

Fig. 2. Calculation Results of Measurement Model (Outer Model) of Organizational Culture Variables

Source: Smart PLS version 3.2.8 


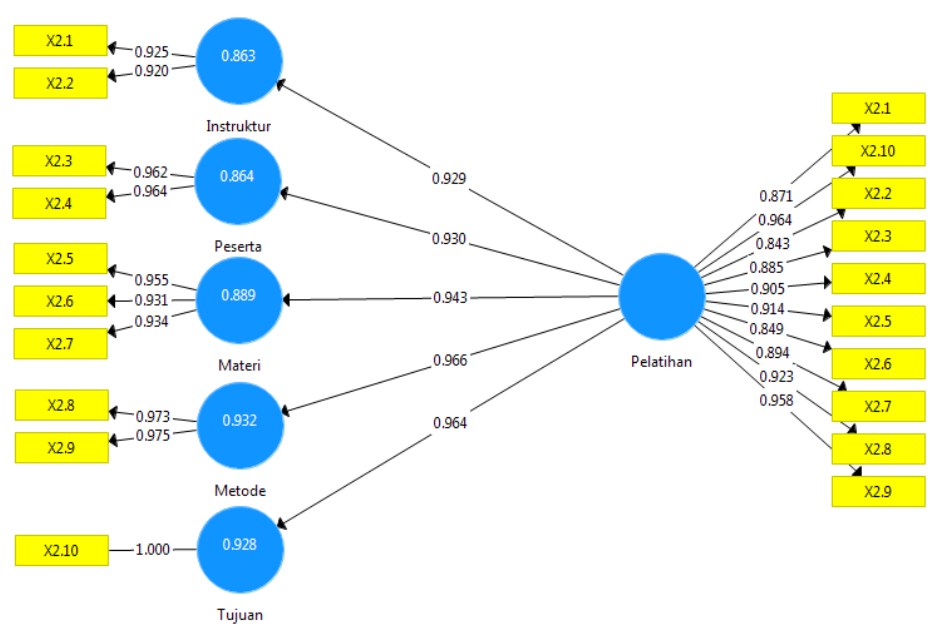

Fig. 3. Calculation Results of Measurement Model (Outer Model) of Training Variables Source: Smart PLS version 3.2.8

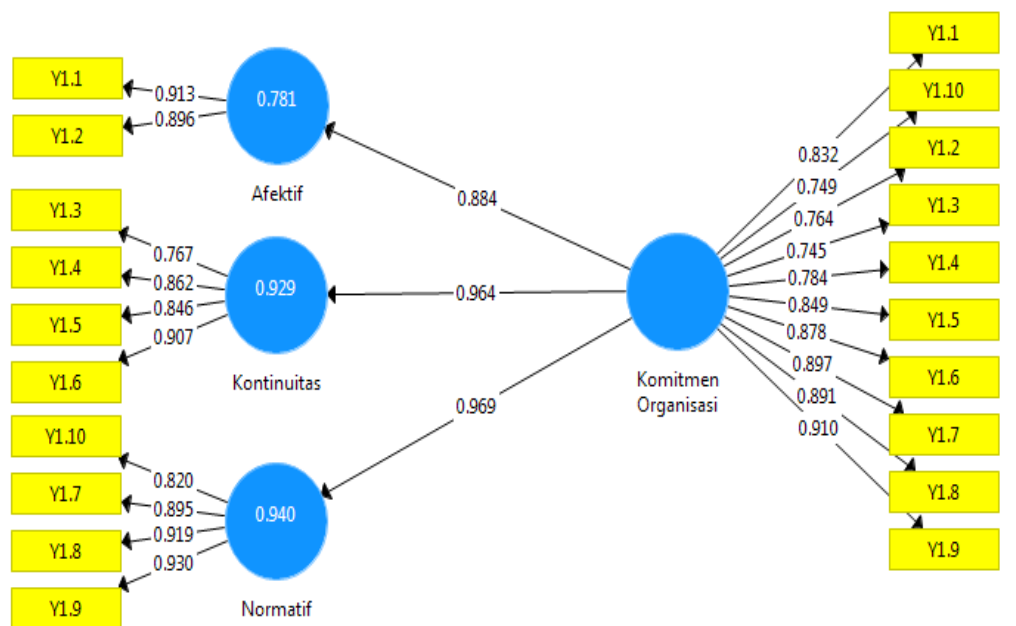

Fig. 4. Calculation Results of Measurement Model (Outer Model) of Organizational Commitment Variables

Source: Smart PLS version 3.2.8

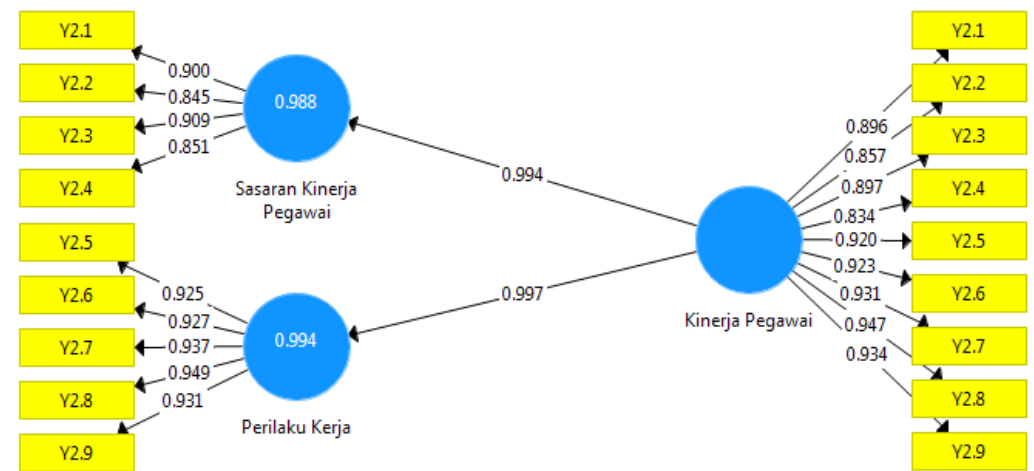

Fig. 5. Calculation Results of Measurement Model (Outer Model) of Performance Variables

Source: Smart PLS version 3.2.8 
Based on the convergent validity results using SmartPLS version 3.2.8 shown in Figure 2 till Figure 5, it can be seen that the indicators on organizational culture, training, organizational commitment and employee performance variables have a loading factor $>0.7$, so that all indicators are declared valid and still used in the model or not removed from the model.

Table 1. Cronbach's Coefficient Alpha and Composite Reliability (CR) Value

\begin{tabular}{lccccc}
\hline \multicolumn{1}{c}{ Variable } & $\begin{array}{c}\text { Composite } \\
\text { Reliability }\end{array}$ & Requirement & $\begin{array}{c}\text { Cronbach's } \\
\text { Alpha }\end{array}$ & Requirement & Information \\
\hline Organizational Culture $\left(\mathrm{X}_{1}\right)$ & 0.972 & $>0,7$ & 0.969 & $>0,6$ & Reliable \\
\hline Training $\left(\mathrm{X}_{2}\right)$ & 0.977 & $>0,7$ & 0.974 & $>0,6$ & Reliable \\
\hline Organizational Commitment $\left(\mathrm{Y}_{1}\right)$ & 0.957 & $>0,7$ & 0.950 & $>0,6$ & Reliable \\
\hline Employee Performance $\left(\mathrm{Y}_{2}\right)$ & 0.976 & $>0,7$ & 0.972 & $>0,6$ & Reliable \\
\hline
\end{tabular}

Source: Smart PLS version 3.2.8

From table 1 it is known that the Cronbach's Coefficient Alpha value for organizational culture, training, organizational commitment and performance variables is more than 0.6 or even close to 1 and the Composite reliability (CR) value is more than 0.7 , so that all the variables in the study are declared reliable.

\section{Inner Model Test}

To evaluate the value of the path coefficient, based on the results of calculations using calculate SmartPLS version 3.2.8 bootstrapping obtained the path coefficient (path coefficient) which illustrates the strength of the relationship between constructs / variables as shown in table 2 and figure 6 below.

Table 2. Path Coefficient Test Results

\begin{tabular}{lcccc}
\hline & $\begin{array}{c}\text { Original } \\
\text { Sample (O) }\end{array}$ & $\begin{array}{c}\text { Sample } \\
\text { Mean (M) }\end{array}$ & $\begin{array}{c}\text { Standard } \\
\text { Deviation } \\
\text { (STDEV) }\end{array}$ & $\begin{array}{c}\text { T Statistic } \\
\text { (O/STDEV) }\end{array}$ \\
\hline $\begin{array}{l}\text { Organizational Culture (X1) -> } \\
\text { Organizational Commitment (Y1) }\end{array}$ & 0.458 & 0.454 & 0.071 & 6.454 \\
\hline $\begin{array}{l}\text { Organizational Culture (X1) -> } \\
\text { Employee Performance (Y2) }\end{array}$ & 0.154 & 0.159 & 0.063 & 2.449 \\
\hline $\begin{array}{l}\text { Training (X2) -> Organizational } \\
\text { Commitment (Y1) }\end{array}$ & 0.474 & 0.480 & 0.074 & 6.000 \\
\hline $\begin{array}{l}\text { Training (X2) -> Employee } \\
\text { Performance (Y2) }\end{array}$ & 0.321 & 0.319 & 0.058 & 5.490 \\
\hline $\begin{array}{l}\text { Organizational Commitment (Y1)-> } \\
\text { Employee Performance (Y2) }\end{array}$ & 0.523 & 0.519 & 0.063 & 0.000 \\
\hline
\end{tabular}

\footnotetext{
Source: Smart PLS version 3.2.8
} 


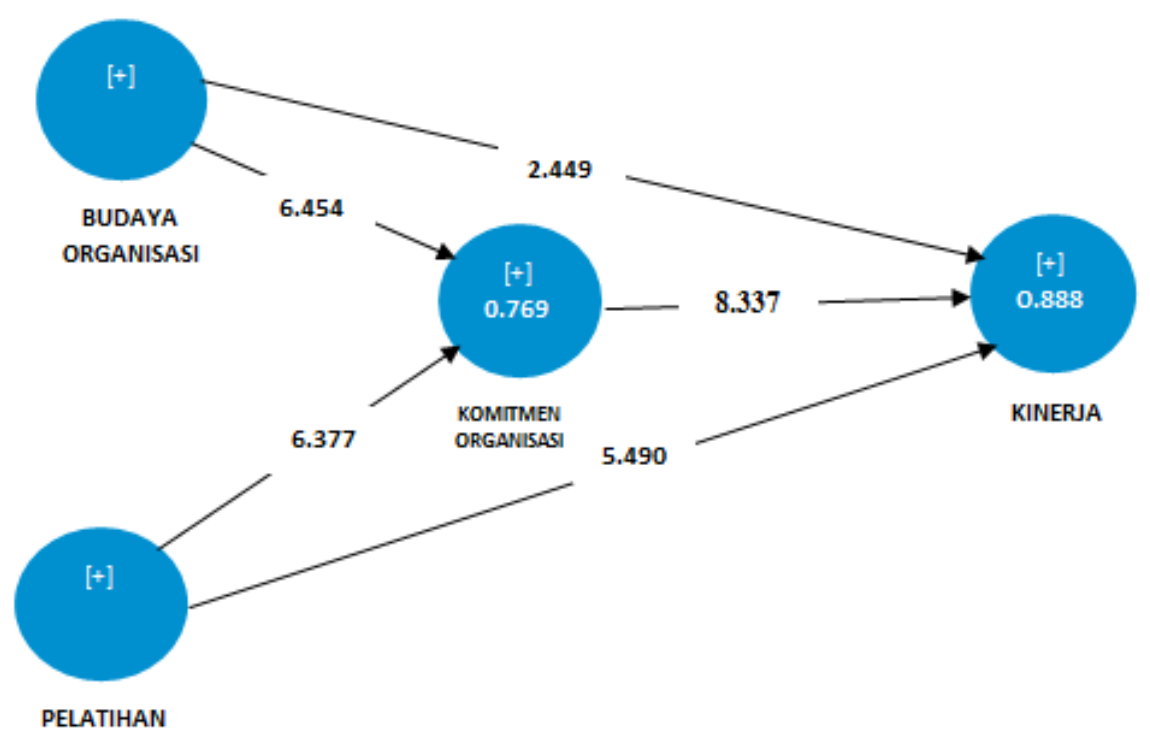

Fig 6. Bootstrapping Inner Model Calculation Results

Source: Smart PLS version 3.2.8 follows:

Based on Figure 6, the structural equation of this research can be formulated as

Organizational Commitment $(\mathrm{Y} 1)=0,458 \gamma 1+0,474 \gamma 2$

Performance $(\mathrm{Y} 2)=0.154 \gamma 3+0.321 \gamma 4+0.523 \gamma 5$

Based on table 2 it can be concluded that:

1) Organizational Culture has an effect of 0.458 on Organizational Commitment with a TStatistic value of 6,454 and P-Values of 0,000.

2) Organizational Culture influences 0.154 on Performance with a T-Statistic value of 2.449 and P-Values of 0.015 .

3) Training has an effect of 0.474 on Organizational Commitment with a T-Statistic value of 6,377 and P-Values of 0,000 .

4) Training has an effect of 0.321 on Performance with a T-Statistic value of 5,490 and PValues of 0,000 .

5) Organizational Commitment has an effect of 0.523 on Performance with a T-Statistic value of 8.337 and P-Values of 0.000 .

\section{R2 Evaluation and F Statistic Test}

To evaluate the value of R2 based on the results of calculations using calculate SmartPLS version 3.2.8 algorithm, the results of the R2 value are 0.769 for the Organizational Commitment variable and 0.888 for the Performance variable. The value of $\mathrm{R} 2$ indicates that the level of determination of exogenous variables (Organizational Culture and Training) towards the endogenous is quite high.

The simultaneous influence of Organizational Culture and Training variables on Organizational Commitment can be done by calculating $\mathrm{f}$ arithmetic / f statistics using the formula as below.

1) $\mathrm{R} 2=0,769$ (Organizational Commitment) 


$$
\begin{aligned}
& \mathrm{F} \text { count } 1 \quad \mathrm{~F}_{\text {count } 1} 1=\frac{\frac{R^{2}}{(k-1)}}{1-R^{2} /(n-k)} \\
& \mathrm{F}_{\text {count } 1} 1=\frac{\frac{0,769}{(4-1)}}{1-0,769 /(120-3)} \\
& \mathrm{F}_{\text {count } 1}=0,385 / 0,001974 \\
& \mathrm{~F}_{\text {count } 1}=194,748
\end{aligned}
$$

So, the F count 1 is (Organizational Commitment variable) namely 194,748

The simultaneous influence of Organizational Culture, Training and Organizational Commitment variables on Performance can be done by calculating $\mathrm{f}$ arithmetic / $\mathrm{f}$ statistics using the formula as below.

2) $\mathrm{R} 2=0,888$ (Performance)

$$
\begin{aligned}
& \mathrm{F}_{\text {count }} 2=\frac{\frac{R^{2}}{(k-1)}}{1-R^{2} /(n-k)} \\
& \mathrm{F}_{\text {count }} 2=\frac{\frac{0,888}{(4-1)}}{1-0,888 /(120-4)} \\
& \mathrm{F}_{\text {count } 2} 2=0,296 / 0.000965 \\
& \mathrm{~F}_{\text {count }} 2=305,376
\end{aligned}
$$

So, the F count 2 is (Performance) namely 305,376

Table 3. R2 Evaluation and F Statistic Test

\begin{tabular}{cccccc}
\hline & R Square & F Statistic & F Table & Alpha & Conclusion \\
\hline$(\mathrm{BO}$, PEL) -> KO & 0.769 & 194.748 & 2.68 & 0.05 & $\begin{array}{c}\mathrm{F}_{\text {count }}>\mathrm{F}_{\text {table }} \\
\left(\mathrm{H}_{6} \text { accepted }\right)\end{array}$ \\
\hline$(\mathrm{BO}, \mathrm{PEL}, \mathrm{KO})->$ KIN & 0.888 & 305.376 & 2.68 & 0.05 & $\begin{array}{c}\mathrm{F}_{\text {count }}>\mathrm{F}_{\text {table }} \\
\left(\mathrm{H}_{7} \text { accepted }\right)\end{array}$ \\
\hline
\end{tabular}

Source: Smart PLS version 3.2.8

Based on the results of the above calculation it can be seen that the calculated $F$ value of 1 in this research is $194,748>\mathrm{F}$ table (2.68) so it is evident that the organizational culture, and training variables together have a positive and significant effect on organizational commitment. While the value of Fcount 2 in this Research is 305,376 > F table (2.68), so it is evident that the organizational culture, training, and organizational commitment variables together have a positive and significant effect on performance.

\section{Indirect Effect}

Estimating the indirect effect simultaneously by adding mediation variables between the independent variable and the dependent variable. In this research, researchers estimated indirect effects, namely the role of organizational commitment variables in mediating the influence of organizational culture variables and training variables on performance variables with the explanation in Figure 7 below. 


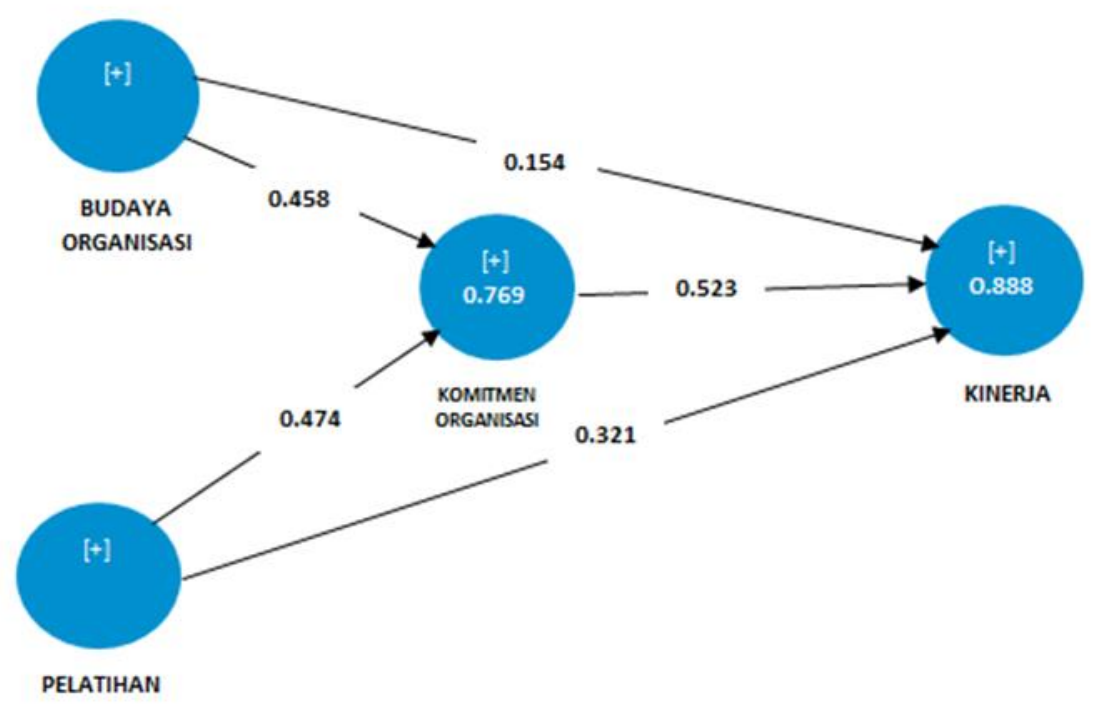

Fig. 7. Indirect Effect Model Test with Smart PLS

Source: Smart PLS version 3.2.8

Based on Figure 7 it is known that the indirect effect of organizational culture and training on performance is as follows:

1) The indirect effect of organizational culture on performance is the coefficient value of direct organizational culture on organizational commitment multiplied by the coefficient value of the direct influence of organizational commitment on performance $(0.458 \mathrm{x}$ $0.523=0.239$.

2) The indirect effect of training on performance is the coefficient value of the direct effect of training on organizational commitment multiplied by the coefficient value of the direct influence of organizational commitment on performance $(0.474 \times 0.523=0.247$.

\section{Correlation Between Dimensions}

Correlation analysis between dimensions aims to measure the level of relationship between dimensions in variable $\mathrm{X}$ with dimensions in variables $\mathrm{Y} 1$ and $\mathrm{Y} 2$ and dimensions in variable Y1 with dimensions in variable Y2. The following results are correlations between dimensions in this research.

Table 4. Correlation Between Dimensions Result

\begin{tabular}{|c|c|c|c|c|c|c|}
\hline \multirow{3}{*}{ Variable } & \multirow{3}{*}{ Dimension } & \multicolumn{5}{|c|}{ Correlations } \\
\hline & & \multicolumn{3}{|c|}{ Organizational Commitment (Y1) } & \multicolumn{2}{|c|}{$\begin{array}{c}\text { Employee Performance } \\
\text { (Y2) }\end{array}$} \\
\hline & & Affectiveness & Continuing & Normative & $\begin{array}{l}\text { Employee } \\
\text { work goal }\end{array}$ & $\begin{array}{l}\text { Behave at } \\
\text { work }\end{array}$ \\
\hline \multirow{6}{*}{$\begin{array}{l}\text { Organizational } \\
\text { Culture (X1) }\end{array}$} & $\begin{array}{l}\text { Innovation and Risk } \\
\text { Thinking }\end{array}$ & 0.714 & 0.684 & 0.725 & 0.779 & 0.771 \\
\hline & Attention to details & 0.642 & 0.699 & 0.729 & 0.769 & 0.765 \\
\hline & Result orientation & 0.669 & 0.661 & 0.686 & 0.725 & 0.723 \\
\hline & Individual orientation & 0.786 & 0.811 & 0.856 & 0.814 & 0.809 \\
\hline & Team orientation & 0.676 & 0.686 & 0.729 & 0.766 & 0.751 \\
\hline & Stability & 0.666 & 0.652 & 0.668 & 0.720 & 0.722 \\
\hline
\end{tabular}




\begin{tabular}{|c|c|c|c|c|c|c|}
\hline & Aggressiveness & 0.732 & 0.752 & 0.731 & 0.759 & 0.752 \\
\hline \multirow{5}{*}{ Training(X2) } & Instructor & 0.693 & 0.741 & 0.759 & 0.853 & 0.838 \\
\hline & Participant & 0.673 & 0.728 & 0.821 & 0.882 & 0.800 \\
\hline & Material & 0.650 & 0.768 & 0.807 & 0.837 & 0.829 \\
\hline & Methods & 0.677 & 0.748 & 0.767 & 0.830 & 0.817 \\
\hline & Aim & 0.612 & 0.716 & 0.757 & 0.796 & 0.781 \\
\hline \multirow{3}{*}{$\begin{array}{l}\text { Organizational } \\
\text { Commitment } \\
\text { (Y1) }\end{array}$} & Affectiveness & - & - & - & 0.874 & 0.874 \\
\hline & Continuing & - & - & - & 0.848 & 0.853 \\
\hline & Normative & - & - & - & 0.879 & 0.872 \\
\hline
\end{tabular}

Source: Smart PLS version 3.2.8

Based on Table 4 above it can be concluded that the correlation between dimensions in this study is as follows:

1) On organizational culture variables on organizational commitment variables, the highest correlation dimension is the orientation dimension of people towards the normative dimension of 0.856 and falls into the category of a very strong relationship level. While the lowest correlation dimension on this variable is the dimension of attention to detail towards the affective dimension, which is equal to 0.642. This explains that the dimension of orientation of people in the organizational culture variables is indispensable for any increase in organizational commitment, especially in the normative dimension.

2) On organizational culture variables on performance variables, the highest correlation dimension is the dimension of people orientation towards the dimensions of employee performance targets, amounting to 0.814 and included in the category of a very strong relationship level. While the lowest correlation dimension on this variable is the dimension of stability to the dimensions of employee performance targets, which is equal to 0.720 . This explains that the dimension of people orientation in the organizational culture variable is indispensable for any improvement in performance, especially in the target dimensions of employee performance.

3) On the training variable on organizational commitment variable, the highest correlation dimension is the participant dimension to the normative dimension, which is 0.821 and belongs to the category of a very strong relationship level. While the lowest dimension correlation on this variable is the objective dimension to the affective dimension, which is equal to 0.612 .

4) This explains that the participant dimension is indispensable for any increase in organizational commitment especially in the normative dimension.

5) On the training variable on the performance variable, the highest correlation dimension is the participant dimension to the target employee performance dimension, which is 0.882 and falls into the category of a very strong relationship level. While the lowest correlation dimension on this variable is the objective dimension to the dimensions of work behavior, which is 0.781 . This explains that the dimensions of the participants in the training are indispensable for any improvement in performance, especially in the dimensions of employee performance targets.

6) On the variable organizational commitment to the performance variable, the highest correlation dimension is the normative dimension to the dimensions of employee performance targets, amounting to 0.879 and included in the category of a very strong 
relationship level. While the lowest correlation dimension on this variable is the continuity dimension to the dimensions of employee performance targets, which is equal to 0.848 . This explains that the normative dimension in the variable organizational commitment is indispensable for any improvement in performance, especially in the target dimensions of employee performance.

\section{Discussion}

1) Hypothesis 1 - Organizational Culture has a significant effect on Organizational Commitment.

Obtained a path coefficient of 0.458 and t count $(6,454)>t$ Table $(1.98)$ with p of 0,000 , thus $\mathrm{H} 1$ is accepted $(\mathrm{p}<0.05)$ and $\mathrm{H} 0$ is rejected, organizational culture has a significant positive effect on organizational commitment. This is consistent with research conducted by Patra and Aima (2018).

2) Hypothesis 2 - Training has a significant effect on Organizational Commitment Obtained a path coefficient of 0.474 and t count $(6,377)>t$ Table (1.98) with p of 0,000 , thus $\mathrm{H} 2$ is accepted $(\mathrm{p}<0.05)$ and $\mathrm{H} 0$ is rejected, training has a significant positive effect on organizational commitment. This is consistent with research conducted by Nugraha, et.al. (2017).

3) Hypothesis 3 - Organizational Culture influences Performance

Obtained a path coefficient of 0.154 and t count (2.449) > t Table (1.98) with p of 0.015 , thus $\mathrm{H} 3$ is accepted ( $\mathrm{p}<0.05)$ and $\mathrm{H} 0$ is rejected, organizational culture has a significant positive effect on performance. This is in accordance with research conducted by Wahyuni (2015).

4) Hypothesis 4 - Training has a significant effect on performance

Obtained a path coefficient of 0.321 and $t$ count $(5,490)>t$ Table (1.98) with p of 0,000 , thus $\mathrm{H} 4$ is accepted $(\mathrm{p}<0.05)$ and $\mathrm{H} 0$ is rejected, training has a significant positive effect on performance. This is in accordance with research conducted by Riyanto, et.al. (2017).

5) Hypothesis 5 - Organizational Commitment influences Performance

Obtained a path coefficient of 0.523 and t count (8.337) > t Table (1.98) with p of 0.000 , thus $\mathrm{H} 5$ is accepted $(\mathrm{p}<0.05)$ and $\mathrm{H} 0$ is rejected, organizational commitment has a significant positive effect on performance. This is in accordance with research conducted by Sakti (2015).

6) Hypothesis 6 - Organizational Culture and Training together influence the Organizational Commitment.

Organizational Culture and Training Variables have (R2) which is 0.769 with a statistical $\mathrm{f}$ value of 194.748 and the $\mathrm{f}$ table value at alpha 0.05 is 2.68 . This means that $\mathrm{f}$ count $(194,748)>\mathrm{f}$ Table (2.68), then H6 is accepted and H0 is rejected. Thus it can be concluded that hypothesis 6 is proven which states that organizational culture and training variables together have a positive and significant influence on organizational commitment.

7) Hypothesis 7 - Organizational Culture, Training, Organizational Commitment together have a significant effect on performance 
The organizational culture, training and organizational commitment variables have (R2) 0.888 with a statistical value of 305.376 and an $f$ table value of alpha 0.05 is 2.68 . This means that $\mathrm{f}$ count $(305,376)>\mathrm{f}$ Table $(2.68)$, then $\mathrm{H} 7$ is accepted and $\mathrm{H} 0$ is rejected. Thus, it can be concluded that hypothesis 7 is proven which states that organizational culture, training and organizational commitment variables together have a positive and significant effect on performance.

8) Hypothesis 8 - Organizational Commitment mediates Organizational Culture and Training on Performance.

The path coefficient value of the direct influence of organizational culture on performance 0.1542 < The path coefficient value of indirect influence of organizational culture on performance is 0.239 and the value of $p$ value of the indirect effect of organizational culture variables on performance mediated by the variable organizational commitment is 0,000 with a $\mathrm{T}$ value of 5,099. The path coefficient value of the direct influence of training on performance 0.3212 < the path coefficient value of the indirect effect of training on performance is 0.247 and the $p$ value of the indirect effect of training variables on performance mediated by the organizational commitment variable is 0,000 with a $\mathrm{T}$ value of 5,293. Because the $\mathrm{p}$ value obtained $<0.05$ and $\mathrm{T}$ statistic $>1.98$ then $\mathrm{HO}$

\section{CONCLUSION AND SUGESTION}

\section{Conclusions}

Based on the results and the discussion above, the authors conclude and provide the following suggestions:

Conclusion

The conclusions of this research are as follows:

1) Organizational culture has a significant positive effect on organizational commitment, with dimension orientation of people that has the strongest influence.

2) The training had a significant positive effect on organizational commitment, with the dimensions of the participants having the strongest influence.

3) Organizational culture has a significant positive effect on performance, with the most powerful influence on the orientation of people

4) The training had a significant positive effect on performance, with the dimensions of the participants having the strongest influence.

5) Organizational commitment as a mediator in this research has a significant effect on performance.

6) Organizational culture and training altogether have a significant positive effect on organizational commitment

7) Organizational culture, training and organizational commitment simultaneously have a positive and significant effect on performance.

8) Organizational commitment is mediating organizational culture and training on performance. 


\section{Suggestions}

1) The "people orientation" dimension of organizational culture variables has the highest correlation with the "employee work objectives" dimension of the performance variable. Therefore, both of these dimensions must be the main concern for improving performance of the health staff of Johar Baru District's Puskesmas. In the aspect of management, performance targets should be well programmed in terms of quality and quantity aspects by considering "people" as implementing activities. In decision made by the leadership, it should be more coordinated with all constructive ideas and opinions.

2) Performance goals must also be synchronized with the training program and prioritize participants who are well selected and enthusiastic

3) So that the performance of health employees can be further enhanced, therefore organizational commitment is an important determinant of aspects of loyalty, moral obligation, order and various benefits that can be received by employees

4) Concretely suggested as it follows:

a) The leadership of the puskesmas attends leadership training on a regular basis so that it can further enhance the commitment of employee organizations and spur employees in carrying out their responsibilities better.

b) A capacity building program needs to be made in which there is a mind management and motivation program for puskesmas employees to be more committed to the responsibility obligations with people within the puskesmas and have a strong mentality to deal with the pressures of the workplace.

c) Internalization of puskesmas values, especially professional values, is reduced to the work culture of employees so that employees are accustomed to jobs that require high levels of professionalism.

d) It is necessary to make a routine motivational program for employees that aims to foster a good work ethic from within the employee.

e) The head of the puskesmas always selects participants well so that the trainees who participate in the training activities are truly people who are in accordance with the jobdesk and their competencies related to the training topic.

f) Conduct an evaluation of the quantity, quality and accuracy of the completion of employee work in Johar Baru District's Puskesmas.

g) Based on the results of the evaluation, providing rewards for employees who perform well and very well so that employee work goals can be maintained and even improved and become a driving factor for employees who lacked performance.

h) Based on the evaluation results, giving punishment to employees who are performing poorly so that it is expected in the future it will increase the quantity, quality, accuracy of the completion of work results better.

\section{REFERENCES}

Allen and Meyer. (2011). The Measurement and Antecedents of Affective, Contintinuance and NormativeCommitment to Organitazion. PT Elex Media Komputindo, Jakarta

Arikunto, Suharsimi. (2013). Prosedur Penelitian Suatu Pendekatan Praktik. Rineka Cipta. Jakarta: Bangun. 
Fahmi, Irham. (2016). Pengantar Manajemen Sumber Daya Manusia Konsep dan Kinerja. Jakarta: Mitra Wacana Media.

Kasmir. (2016). Manajemen Sumber Daya Manusia. Edisi 1.Cetakan 2: PT. Raja Grafindo Persada.

Mangkunegara. Prabu. (2011). Evaluasi Sumber Daya Manusia. Bandung: PT. Refika Aditama.

Mangkunegara, Prabu. (2015). Manajemen Sumber Daya Manusia Perusahaan. Bandung: PT. Remaja Rosda Karya.

Nugraha, Reza Septian, Margono Setiawan, Astrid Puspaningrum. (2017). Komitmen Organisasional sebagai Mediasi Pengaruh Pelatihan dan Disiplin Kerja Terhadap Kinerja Pegawai (Studi pada Dinas Pendapatan Pengelolaan Keuangan dan Asset Kabupaten Malang). Jurnal Bisnis dan Manajemen Vol. 4 No.1, Januari 2017

Patra, Anggi dan M. Havidz Aima (2018). The Effect of Organizational Culture and Job Satisfaction on Organizational Commitments and the Implementation on Organizational Citizenship Behavior in Employee of PT. Bali Towerindo Sentra Tbk. International Journal of Scientific and Research Publication, Vol. 8, Issue 12. ISSN 2250-3153. DOI: 10.29322/IJSRP.8.12.2018.p8443.

Peraturan Pemerintah Republik Indonesia Nomor 46 Tahun 2011 Tentang Penilaian Prestasi Kerja Pegawai Negeri Sipil.

Ricardianto, Prasadja. (2018). Human Capital Management: PT. IN MEDIA.

Riyanto, Setyo, Ria Rahma Yanti, Hapzi Ali. (2017). The Effect of Training and Organizational Commitment on Performance of State University of Jakarta Student Cooperative (KOPMA UNJ) Management. Saudi Journal of Humanities and Social Sciences. ISSN 2415-6256. DOI: 10.21276/sjhss.

Robbins., Coulter. (2010). Manajemen. Jilid 1.Edisi 10: PT. Gelora Aksara Pratama.

Robbins, Stephen P \& Judge, Timothy A. (2013). Organizational Behavior Edition 15. New Jersey: Pearson Education.

Sakti, Baskoro Kurnia. (2016). Pengaruh Kompensasi, Pelatihan dan Komitmen Organisasi Terhadap Kinerja Karyawan pada SPBU di Boja. Faculty of Economy \& Business. DINUS University.

Sinambella, Poltak. (2018). Manajemen Sumber Daya Manusia. Cetakan 3: PT Bumi Aksara. Sugiyono. (2013). Metode Penelitian Kuantitatif, Kualitatif dan R\&D. Bandung: CV. Alfabeta.

Undang-Undang Republik Indonesia Nomor 13/2003 tentang Ketenagakerjaan.

Wahyuni, Evi. (2015). Pengaruh Budaya Organisasi dan Gaya Kepemimpinan Terhadap Kinerja Pegawai Bagian Keuangan Organisasi Sektor Publik Dengan Motivasi Kerja Sebagai Variabel Intervening (Studi Kasus pada Pegawai Pemerintah Kota Tasikmalaya). Jurnal Nominal, Vol. IV, No.1.

Wibowo. (2017). Manajemen Kinerja. Jakarta: PT. Raja Grafindo Persada. 